\title{
Growth, mortality and recruitment of Periopthalmus barbarus (Linneaus 1766 ) in New Calabar River, Nigeria
}

\author{
K.O.Chukwu, and S.N.Deekae \\ Department of Fisheries and Aquatic Environment, Rivers State University of Science and \\ Technology, Port-Harcourt Rivers State, Nigeria. \\ Corresponding E-mail. king4c2004@yahoo.com
}

\begin{abstract}
A sample size of 1572 was collected in the study and estimates of the growth, mortality and recruitment of Periophthalmus barbarus over a twelve month period in New Calabar River Nigeria. Applying the Von Bertalanffy function gave the value of the growth coefficient $(K)$ as $0.65 \mathrm{yr}^{-1}$, while length infinity $\left(L_{o 0}\right)$ was $15.28 \mathrm{~cm}$ by Shephard's method.The Powell Wetheral's plot gave $L_{o o}$ as $10.73 \mathrm{~cm}, Z / K 0.569$ and the function $Y=6.84+(-0.637)^{\star} X$. Length at age $\left(t_{o}\right)$ was 0.16 . The growth performance index (ǿ) was 2.181.From length converted catch curves total mortality (Z) was $2.03 \mathrm{yr}^{-1}$, natural mortality (M) $1.68 \mathrm{yr}^{-1}$ and fishing mortality $(F) 0.35 \mathrm{yr}^{-1}$. Exploitation rate was 0.17 and Emax 0.421 . Length at first capture from relative yield/recruit analysis (knife edge ) (Lc) was $0.76 \mathrm{~cm}$ and $\mathrm{Lc} / \mathrm{L}_{\mathrm{oo}}$ was 0.050 .
\end{abstract}

Keywords; Growth, Mortality, Recruitment, Periophthalmus barbarus.

\section{INTRODUCTION}

The mudskipper Periophthalmus barbarus is a finfish of the littoral shallow and exposed Intertidal mudflats of estuarine mangrove swamps in the gulf of guinea. It is amphibious. It is predominantly a brackish water inhabitant and the only species in the genus Periophthalmidae that is found in the gulf of guinea (Schneider, 1990).

Growth in fish is normally measured in length and weight. From such studies the growth, age and other population parameters a fish can be estimated. . King (1995) stated that sustainable management of a fishery requires a body of knowledge concerning the dynamics of fish population. Furthermore, Ricker (1978) pointed out that the theory of population dynamics is a division of the general theory of the laws of reproduction, growth and the causes of death of living organisms. Musick (1999) reported that the ability of a stock to sustain its population is a function of its resilience to fishing pressure and productivity. This to a large extent depends on its reproductive capacity or fecundity in addition to survival in its natural environment. In view of this the American Fisheries Society (AFS) has suggested values for several levels of biological parameters that are required to allow for the classification of fish populations or species into categories of high, medium low and very low resilience or productivity ( Pamela et al 2001, Musick !999). The need to monitor the changes in the population of a stock especially with changes in the environment is crucial; (Larkin 1978) reported changes in the population of Pacific Salmon following changes in the environment as a result of human activities.

Studies by Etim et al., (2002) on Periophthalmus barbarus in Imo estuary gave the following figures for its population parameters Length infinity $\left(\mathrm{L}_{\mathrm{oo}}\right)$ $21.6 \mathrm{~cm}$, Parameter of curvature $(\mathrm{K})=0.55 \mathrm{yr}^{-1}$, total mortality $(Z)=4.21 \mathrm{yr}^{-1}$, instantaneous natural mortality coefficient $(M)=1.35 \mathrm{yr}^{-1}$, and instantaneous fishing mortality $(F)=2.86 \mathrm{yr}^{-1}$. The paper also reported an over exploitation rated $(E)$ of 0.68 as against the predicted rate of 0.5 for maximum $E$. This paper is intended to expose the exploitation level and state of the stock in the New Calabar River

\section{MATHERIALS AND METHODS}

The study was carried out in New Calabar River. The river lies within $4^{0} 15^{1} \mathrm{~N}$ and $4^{0} 45^{1} \mathrm{~N}$ and $6^{0} 57^{1}$ and $7^{0} 04^{1} \mathrm{E}$. The sampling was done at Eagle cement region of the river.

Samples were collected biweekly for each month from February 2008 to January 2009. The fish was caught using traps made from bamboo. They were $30 \mathrm{~cm}$ long and had a diameter of $5 \mathrm{~cm}$. The traps were buried in the mud flat at low tide with smashed Uca tangeri (West African Fiddler crab) Sprinkled around it to attract the mudskippers. Three traps were used and positioned about 30 meters apart, and left for about one hour. Samples were pooled 
together and preserved in $10 \%$ formaldehyde solution. Measurements were carried out for total length (TL) using a measuring board to the nearest $0.01 \mathrm{~cm}$. Weights of samples were measured by a top loading weighing balance to the nearest $0.01 \mathrm{~g}$.

The growth parameters were estimated using the Von bertalanffy growth function $L_{t}=L_{o o}\left(1-e^{-K(t-t o)}\right)$

(Forese and Binohlan 2000)

Where

$L_{t} \quad$ - $\quad$ Length at age $t$

$L_{\circ o} \quad$ - $\quad$ Length infinity or asympototic length (mean length of very old fish).

$\mathrm{K} \quad$ - $\quad$ Parameter of curvature (Provides the rate at which the fish approach $L \alpha$ )

$t_{0} \quad-\quad$ Age of fish at length zero.

The yield per recruit (Y/R) was obtained by the Beverton and Holt (1957), Froese et al (2005) function $\mathrm{Y} / \mathrm{R}=\mathrm{Y}^{1} / \mathrm{R}^{*}\left(\mathrm{~W}_{\mathrm{oo}}{ }^{*} \mathrm{e}^{\wedge}-\left(\mathrm{NI}\left(\mathrm{tr}-\mathrm{t}_{\mathrm{o}}\right)\right)\right)$

$\begin{array}{ccl}\text { Where } Y & - & \text { Yield } \\ R & - & \text { Recruitment (Recruit) } \\ y^{1} & - & \text { Relative Yield } \\ W_{o o} & - & \text { Weight infinity } \\ M & - & \text { Natural mortality } \\ \operatorname{tr} & - & \text { Age at recruitment } \\ t_{0} & - & \text { Age of fish at length zero }\end{array}$

Mortality:

The instantaneous total mortality $(Z)$ was estimated from length converted catch curve analysis as reported by Pauly (1983a, 1984a and b),Sparre and Venema (1998). While Powell plot (1979), and discussed by Wetherall et. al. , (1987) gave the value of $\mathrm{Z} / \mathrm{K}$ with equation given thus,

$\begin{array}{rcc}\mathrm{Z} / \mathrm{K}= & & (1+\mathrm{b}) / \mathrm{b} \text { and } L_{\circ o}=-\mathrm{a} / \mathrm{b} \\ \text { Where } \mathrm{K}- & & \text { Parameter of curvature. } \\ & \mathrm{b}- & \text { Slope. } \\ & \mathrm{a}- & \text { Intercept }\end{array}$

The instantaneous natural mortality (M) was Pauly's empirical formula (Pauly, 1980b) and the fishing mortality obtained from the equation

$\mathrm{Z}=\mathrm{F}+\mathrm{M}$.
Where F - Instantaneous Fishing mortality.

M - Instantaneous Natural mortality

The exploitation rate $(E)$ was obtained from $E=F / Z$ (where $Z=F+M)$ (Pauly 1984).

The entire population parameter estimates were obtained using the FISAT package (Etim et. al., 2002).

\section{RESULTS}

Results of length-weight measurements ( $n=1572)$ gave the following ranges, length $4.1 \mathrm{~cm}-14.2 \mathrm{~cm}$, and weight $0.70 \mathrm{~g}-39.62 \mathrm{~g}$. . The mean length of samples was $8.64 \pm 1.27 \mathrm{~cm}$ and the mean weight was $11.16 \pm 7.29 \mathrm{~g}$.

Analysis of growth using the Shepherds method gave Asymptotic length $\left(L_{o o}\right)$ as $15.28 \mathrm{~cm}$ and the Von Bertalanffy growth function constant $(\mathrm{K})$ as $0.65 \mathrm{yr}^{-1}$. Estimates from Powell Wetherall's plot gave $L_{o o}$ as $10.73 \mathrm{~cm}, Z / \mathrm{K} 0.569$, and the function $Y=6.84+(-$ $0.637)^{\star} X$. The length at age growth analysis gave a $t_{0}$ as 0.16 . The growth performance index (ǿ) was 2.181. From the length at age analysis, the maturity age of the species was about $12-18$ months. Furthermore, the modal class which is $7-9 \mathrm{~cm}$ fell between the ages of 1-1.5years. The length at which $50 \%$ of samples matured was $10.4 \mathrm{~cm}$ for females and $10.8 \mathrm{~cm}$ for males and $L_{m} / L_{o o}$ ( where $L_{m}$ is length at first maturity) is 0.68 for females and 0.71 for males.

The length converted catch curves gave $Z$ as $2.03 \mathrm{yr}^{-}$ 1; Natural mortality (M) $1.68 \mathrm{yr}^{-1}$ at $30.0^{\circ} \mathrm{C}$, Fishing mortality was $0.35 \mathrm{yr}^{-1}$, Exploitation rate 0.17 ,

$\mathrm{E} 10=0.355, \mathrm{E}-50=0.278$, and $\mathrm{Emax}=0.421$. Relative Yield/ Recruit Analysis (Knife edge) generated the following results, length at first capture (LC) $0.764 \mathrm{~cm}$ and $L C / L_{\circ o} 0.050$. The observed recruitment had two peaks.

\section{DISCUSSION}

Studies by Etim et.al, (2002) on Periophthalmus barbarus in Imo River Estuary gave the following results; $\mathrm{K}=0.55 \mathrm{yr}^{-1}, \mathrm{~L}_{\mathrm{oo}}=21.6 \mathrm{~cm}, \quad \mathrm{Z}=4.21 \mathrm{yr}^{-1}$, $\mathrm{M}=1.35 \mathrm{yr}^{-1}, \mathrm{~F}=2.86 \mathrm{yr}^{-1}, \Phi=2.41$ and $\mathrm{E}=0.68$. This shows an increased exploitation rate at in the Imo River over the New Calabar River. In comparisons with other Gobiids, $P$ barbarus can be said to have an average growth rate. The growth curves of fish are not linear and such cannot be compared directly in biological terms. Therefore the comparison must be done in consideration of a number of other growth 
parameters which includes $\mathrm{K}$ and $\mathrm{L}_{o o}$. $\mathrm{A}$ brief enumeration of some of these are; Boleophthalmus pectinirostris (male) 1.39yr $\mathrm{yr}^{-1}$, (Female) $\mathrm{K}=1.07 \mathrm{yr}^{-1}$ 1.39, Jeong et al., 2004, Gobius niger $\mathrm{K}=0.34 \mathrm{yr}^{-1}$ Silva \& Gordo, 1997 Gobius paganellus K=0.89yr ${ }^{-1}$ Azevedo \& Simas, (2000). Berverton (1992) stated that the value of $L_{m} / L_{o o}$ should range from 0.4 to 0.88. The values of $L_{m} / L_{o o}$ for this species are apparently above average. The current exploitation rate of 0.17 is grossly on the low side and requires some increased levels. This would be necessary to reduce a waste of the stock through natural means (mortality).However, this should be done with some caution and modification to correct what could be regarded as a skewed exploitation situation. From the observed length at first maturity and the modal class of the overall stock, it is evident that most of the catches are just below the size at which the fish does its first breeding. This situation can be checked only if the gear used in harvesting this fish is changed as the trap is not selective nor does it allow the escape of undersized catches. Where it is not possible to device a selective gear, fishers should be encouraged to return immature ones to the water as in most cases they are seen littered on the intertidal zone where they die of asphyxia.

\section{REFERENCE}

Azevedo JMN and Simas AMV (2000) Age and growth, reproduction and diet of a sublittoral population of rock goby Gobius paganellus (Teleostei, Gobbidae). Hydrobiologia 440: 129-135.

Berverton, R.J.H. and S.J. Holt (1957). On the dynamics of exploited fish populations, MAFF Fish. Inv. Ser II, 19, $533 p p$

Beverton, R.J.H, (1992) Patterns of reproductive strategy parameters in some marine teleost fishes. J.Fish.Biol.41:137-160.

Etim L, King P. R, Udo T. M (2002) Breeding, growth, mortality and yield of the mudskipper Periophthalmus barbarus (Linneaus 1766) (Teleostei Gobiidae) in the Imo River Estuary. Nig. Fis. Res.56(3):277-238

Froese, R. and C. Binohlam. (2000). Empirical relationships to estimate asymptotic length, length at first maturity and length at maximum yield per recruit in fishes, with a simple method to evaluate length frequency data. $\mathrm{J}$. Fish Biol. 56; 758 - 773
Froese R, M. Lourdes, D. Palomares and D. Pauly (2005) Estimate of life- history key facts. Available at www.fishbase.com as at November $30^{\text {th }} 2009$.

King M. (1995) Fisheries biology assessment and management . Fish News Book Blackwell Science Ltd. London. 341pp

Larkin D.A (1978) Pacific salmon. In: Gulland J .A. Ed. Fish population Dynamics. John Wiley and Sons Ltd. P157186.

Musick, J. A (1999) Criteria to define exploitation risk in marine fishes. Fisheries 20(12):6-14.

Pamela,M.M.,W.B.Norman.,A.B.Hollowed.,P.Kleiber.,R.D. Methot.,S.A.Murawski.,J.E.Powers and G.P.Scott (2001).Marine fisheries stock improvement plan. Report of the national marine fisheries service national task force for improving fish stock assessments. NOAA Technical Memorandum NMFS-F/SPO-56

Pauly. D, (1980b) On the interrelationships between natural mortality, growth parameters and mean environmental temperature in 175 fish stocks.J.Cons.CIEM,39(2):175192

Pauly, D. (1983a) Length-converted catch curves. A powerful tool for fisheries research in the tropics. (Part 1). ICLARM Fishbyte 1(2):9-13

Pauly. D,(1984a) Length-converted catch curves. A powerful tool for fisheries research in the tropics (Part II).ICLARM Fishbyte 2(1):17-19

Pauly.D,(1984b) Length-converted catch curves.A powerful tool for fisheries research in the tropics (III Conclusion).ICLARM Fishbyte 2(3):9-10

Powell, D.G. (1979). Estimation iof mortality and growth parameters from the length frequency of catch. Rapp. P.V. Renn. CIEM 175:167-169

Ricker. W. E (1978) The historical development. In: Gulland J.A.Ed. Fish population Dynamics. John Wiley and Sons Ltd. pp 1-26.

Sparre, P and S.C. Venema. (1998). Introduction to tropical fish stock assessment-part 1: manual. FAO Fisheries Technical Paper 306/1 Rev. 2. Rome, FAO. 1998. $407 p$

Wetheral J.A.,J.J. polovina and S. Rais ton. (1987). Estimating growth and mortality in steady state fish stocks from length frequency data. ICLARM cont. pre (13) 53-74 